\title{
Correlation among fecal indicator bacteria and physicochemical parameters with the presence of Helicobacter pylori DNA in raw and drinking water from Bogotá, Colombia
}

\author{
Fidson-Juarismy Vesga ${ }^{1,2}$ (D) | Yolanda Moreno ${ }^{2}$ | María Antonia Ferrús ${ }^{3}$ | \\ Lina María Ledesma-Gaitan ${ }^{1}$ | Claudia Campos ${ }^{1}$ | Alba Alicia Trespalacios ${ }^{1}$
}

${ }^{1}$ Science Faculty, Microbiology

Department, Pontificia Universidad

Javeriana, Bogotá, Colombia

${ }^{2}$ Research Institute of Water Engineering and Environment (IIAMA), Universitat

Politécnica de València, Valencia, Spain

${ }^{3}$ Biotechnology Department, ETSIAM,

Universitat Politécnica de València, Valencia, Spain

\section{Correspondence}

Fidson-Juarismy Vesga, Science Faculty, Microbiology Department, Pontificia

Universidad Javeriana, Bogotá, Colombia.

Email: vesga.f@javeriana.edu.co

Funding information

COLCIENCIAS, Colombia, and Project Grant from Generalitat Valenciana, Spain. We greatly acknowledge the collaboration of the Aqueduct and Sewage Company of Bogotá (EAB), Colombia., Grant/Award Number: Project 120356933870, СTO 642-2013 AND AICO/2018/2

\begin{abstract}
Background: The quality of raw and drinking water is a matter of considerable concern due to the possibility of fecal contamination. To assess the quality and public health risk of different types of water, the fecal indicator bacteria (FIB) are used. However, some pathogens, such as Helicobacter pylori, may be present in water when FIB cannot be found. $\mathrm{H}$ pylori is recognized as the causative agent of chronic gastritis, peptic and duodenal ulcers, and gastric cancer. The aim of this study was to evaluate the relationships among physicochemical parameters, FIB concentrations, and the presence of $H$ pylori DNA in raw and drinking water from Bogotá, Colombia.

Materials and Methods: A total of 310 water samples were collected 1 day per week from July 2015 to August 2016, and physicochemical parameters (pH, turbidity, conductivity, and residual free chlorine) were measured. Presence of $H$ pylori DNA was determined and quantified by quantitative polymerase chain reaction (qPCR). Fecal indicator bacteria (total coliforms, Escherichia coli, and spores of sulfite-reducing Clostridia) were enumerated by using standard culture techniques.

Results: Thirty of 155 (31\%) raw water samples and forty-eight of 155 (38.7\%) drinking water samples were positive for the presence of $\mathrm{H}$ pylori. No statistically significant relationships were found between physicochemical parameters or FIB with the presence or absence of $H$ pylori in any sample $(P<0.05)$.

Conclusions: This study provides evidence of the presence of $H$ pylori DNA in raw and drinking water in Bogotá, and shows that the detection and enumeration of FIB and physicochemical parameters in water do not correlate with the risk of contamination with $\mathrm{H}$ pylori.
\end{abstract}

KEYWORDS

drinking water, fecal indicator bacteria, Helicobacter pylori, physicochemical parameters, qPCR, raw water

\section{1 | INTRODUCTION}

Microbiological contamination of water can occur along a water supply system, from the water source(s) to the treatment plant. Water utilities monitor water quality at sources and treatment plants ${ }^{1}$ and take necessary action if required. However, outbreaks of waterborne disease can appear as a result of the entrance of pathogens into distribution systems. ${ }^{2}$ 
Thus, the drinking water may contain at least small amounts of some contaminants. For these reasons, in 2016 the US Environmental Protection (EPA) published the final Contaminant Candidate List 4 (CCL 4), which includes 97 chemicals and 12 microbial contaminants (Adenovirus, Caliciviruses, Enterovirus, Hepatitis A virus, Campylobacter jejuni, Escherichia coli (0157), Helicobacter pylori, Legionella pnuemophila, Micobacterium avium, Salmonella enterica, Shiguella sonnei, and Naegleria fowleri). These contaminants are significant pathogens for public health due to its association with multiple diseases. $^{3}$

Among these contaminants, $\mathrm{H}$ pylori is a microorganism that infects humans, with a global prevalence of $50 \% .{ }^{4-6}$ In developing countries, about $70-90 \%$ of adults show serological evidence of current or past infection with $\mathrm{H}$ pylori. ${ }^{7}$ The rate of infection in Colombia is estimated to reach $70 \%-80 \%$ of the general adult population. ${ }^{8}$ Infection rates are considerably lower in the developed world; for example, the rate of infection in the United States is estimated at $10-25 \%$ of the general adult population. ${ }^{9} \mathrm{H}$ pylori is recognized as the causative agent of chronic gastritis, peptic, and duodenal ulcers, and the etiologic agent in gastric cancers ${ }^{4,6,10}$ and, in 1994, the World Health Organization International Agency for Research on Cancer designated $\mathrm{H}$ pylori as a Class I carcinogen and issued a gastric cancer warning. ${ }^{11}$

Although $\mathrm{H}$ pylori has been proposed as a new drinking water contaminant, few studies have standardized procedures for its detection in water. This is because $\mathrm{H}$ pylori is a dimorphic Gram-negative bacillus, which shows a spiral form in its cultivable state, but can adopt a coccoid morphology under conditions of stress, ${ }^{12}$ entering a viable but nonculturable (VBNC) state, in which the bacterium is unable to grown on agar plates by using conventional culture methods. ${ }^{13}$ VBNC cells retain membrane integrity, and contain undamaged genetic information. These forms have been suggested to be the way in which $\mathrm{H}$ pylori survives in environment. ${ }^{14}$

Although the form of transmission of the $\mathrm{H}$ pylori has not been precisely defined, and the oral-oral or oral-fecal routes are proposed, the role of the presence of viable coccoid but nonculturable forms in the environment is not yet understood. ${ }^{9,15}$ While it has not been demonstrated that $H$ pylori can be transmitted through drinking water, there is increasing interest in knowing how the presence of this contaminant can influence water quality and whether or not it may have an impact on public health. Especially, because $H$ pylori is a frequent colonizer of the human stomach.

The presence of $\mathrm{H}$ pylori DNA in drinking water, surface water groundwater, and wastewater has been previously reported. ${ }^{15-17}$ Moreover, there has been some controversy about the efficiency of chlorination and ozonation disinfection methods to inactivate some pathogens resistant to chlorine, such as $\mathrm{H}$ pylori. ${ }^{12,18}$

Recently, different independent studies have isolated and cultured $\mathrm{H}$ pylori from wastewater and drinking water. ${ }^{5,16,17,19,20}$ In addition, $\mathrm{H}$ pylori has been reliably detected in diverse water sources, such as rivers, lakes, drinking water, municipal, and residual waters, among others, by using molecular biology techniques such as PCR, quantitative real-time polymerase chain reaction (qPCR), and fluorescent in situ hybridization. ${ }^{17,21-25}$
Detecting a waterborne pathogen is difficult, and thus, standard methods are directed to detect nonpathogenic organisms commonly found in human feces. Traditional assessments of microbiological water quality have focused on the presence of fecal indicator bacteria (FIB), whose concentration or density is related to the health risk posed by this water. Fecal indicator bacteria are nonpathogenic organisms, abundant in human and animal feces where pathogenic organisms can be found. ${ }^{26}$ Fecal indicator bacteria presence is usually associated with agricultural operations, cattle management, or human habitation. Determination of FIB is, at the moment, the most used method to predict the presence of pathogens in water resources and drinking water ${ }^{9}$ but these indicator organisms are only weakly associated with the presence of some pathogens. ${ }^{27,28}$ Moreover, measurements of fecal indicator organisms in water can be highly variable. ${ }^{29}$ Traditionally, culture techniques have been commonly used to enumerate $E$ coli and total coliforms in raw and drinking water. ${ }^{30,31}$ However, some authors have pointed out that some pathogens, such as $\mathrm{H}$ pylori, can be able to survive when these indicators are inactivated. ${ }^{5,32,33}$ Thus, the enumeration of coliform bacteria as indicators of drinking water quality may not correlate accurately with the risk this water possesses to consumers. ${ }^{27,32,34}$ There are few studies that look for indicator microorganisms different from the traditional ones to monitor water quality.

Consequently, pathogens as $\mathrm{H}$ pylori are not directly monitored in water. However, a predictive value of water quality indicators with regard to the presence of pathogens has not been established or quantified and, the correlation has not been estimated between them. In addition, given of the difficulty of determining $H$ pylori in raw and drinking water, it was suggested that the variations presented by the physicochemical parameters $(\mathrm{pH}$, turbidity, conductivity, and residual free chlorine) could give some indicative of the presence of it pathogen, taking into account that these parameters are the ones that are routinely measured in the entrance and exit of the water treatment plants. Therefore, in this study, we analyzed the relationships between water quality and presence of $H$ pylori DNA in raw water and drinking water from Bogotá city, Colombia, due to the absence of information related to this issue. A specific aim of this study was to determine whether a numerical correlation could be found between counts of FIB (total coliforms, E coli, and spores of sulfite-reducing Clostridia) and physicochemical parameters $(\mathrm{pH}$, turbidity, conductivity, and residual free chlorine) in raw and drinking water and $H$ pylori DNA detection. We evaluated the presence of FIB by using conventional microbiological analyses and the $\mathrm{H}$ pylori DNA was detected through the qPCR.

\section{2 | METHODS}

\section{1 | Water sampling}

Sample collection and characterization of water physical, chemical, and biological quality of raw and drinking water were carried out using standard methodologies. ${ }^{35}$ 
Between July 2015 and August 2016, a total of 310 samples coming from both, raw water $(n=155)$ and drinking water $(n=155)$, were taken with a weekly frequency. From each sample point, different amounts of water were taken into sterile bottles, as described above.

The raw water samples were taken from 3 three different points of the catchment of superficial waters, it which possess a different concentration of fecal contamination, and which it is subjected to a disinfection treatment with chlorine, and after is distributing as drinking water to Bogotá city, Colombia. Drinking water samples were collected from three different points of the same city.

For $\mathrm{H}$ pylori detection in drinking water samples, the "Moore swab" method was used. ${ }^{35,36}$ Briefly, a swab was kept in contact with drinking water flow for 72 hours, removed and placed into a sterile bottle. For analysis of $\mathrm{H}$ pylori in raw water samples, $300 \mathrm{~mL}$ of water was collected into $500 \mathrm{~mL}$ sterile bottles.

Samples for determining total coliforms, E coli, and spores of sulfite-reducing Clostridia (SSRC) were taken following the Standard Methods 9006 A-3 protocol. ${ }^{35}$ Briefly, for the analysis of total coliforms and E coli from raw water, $200 \mathrm{~mL}$ was sampled into $300 \mathrm{~mL}$ sterile bottles. From drinking water, $700 \mathrm{~mL}$ was collected into $1 \mathrm{~L}$ sterile bottles. For the analysis of spores of sulfite-reducing Clostridia, $500 \mathrm{~mL}$ was sampled from both, raw and drinking water, and held in anaerobic conditions until processing. All raw and drinking water samples were held at $4^{\circ} \mathrm{C}$ and processed within a few hours.

\subsection{Culture conditions and bacterial strain}

The reference strains E coli ATCC 25992 and Salmonella enterica subsp enterica serovar Entiritidis 13076 ATCC were cultured in Nutrient Agar (Merk, Germany) and incubated under aerobic conditions at $36 \pm 2{ }^{\circ} \mathrm{C}$ for 24 hours. Clostridium perfringens 262 CMPUJ strain was cultured in Nutrient Agar (Merk, Germany) and incubated under anaerobic conditions (AnaeroGen ${ }^{\mathrm{TM}} 2.5 \mathrm{~L}$, Thermo Scientific, USA) at $37 \pm 2{ }^{\circ} \mathrm{C}$ for 24 hours. Reference strains were used as positive controls for quantification of FIB.

\section{3 | Detection of $H$ pylori using qPCR analysis and DNA sequencing}

Each raw water sample was centrifuged at $3000 \times \mathrm{g}$ for 20 minutes, and the pellet was resuspended in $2 \mathrm{~mL}$ of phosphate-buffered saline (PBS 1×: $130 \mathrm{mmol} / \mathrm{L}$ sodium chloride, $10 \mathrm{mmol} / \mathrm{L}$ sodium phosphate, $\mathrm{pH}$ 7.2).

For the drinking water samples, the swab was transferred to $200 \mathrm{~mL}$ of Brucella Broth (Becton Dickinson BBL ${ }^{\mathrm{TM}}$, USA) supplemented (BBS) with $0.4 \%$ Isovitalex (Becton Dickinson BBL ${ }^{\mathrm{TM}}$, USA) and $0.2 \%$ Dent (Oxoid, USA) for sample elution and incubated at $37^{\circ} \mathrm{C}$ under microaerophilic conditions $\left(5 \% \mathrm{O}_{2}, 11 \% \mathrm{CO}_{2}, 85 \% \mathrm{~N}_{2}\right)$ for 24 hours. After this pre-enrichment step, each sample was centrifuged at $3000 \times \mathrm{g}$ for 20 minutes and the pellet was resuspended in PBS $1 \times$
Both, raw and drinking PBS suspension samples were concentrated by immunomagnetic separation (IMS) according to Enroth and Engstrand. ${ }^{37}$ The bead-bacterium aggregates were finally resuspended in PBS $1 \times$ and subsequently analyzed by qPCR. Quantitative real-time polymerase chain reaction positive results were confirmed by sequencing. DNA was purified from a $1 \mathrm{~mL}$ aliquot of each IMS concentrated sample using the DNeasy Blood \& Tissue kit (Qiagen, USA), according to the manufacturer's instructions.

Specific $H$ pylori qPCR was carried out using a set of primers to amplify a $372 \mathrm{bp}$ fragment of the vacA gene (VacF: 5'-GGC ACA CTG GAT TTG TGG CA- 3' y vacR: 5'-CGC TCG CTT GAT TGG ACA GA- $3^{\prime}$ ). ${ }^{38}$ For qPCR analysis, the final reaction volume of $20 \mu \mathrm{L}$ contained $2 \mu \mathrm{L}$ of Light-Cycler ${ }^{\circledR}$ FastStart DNA SYBR Green I (Roche Applied Science, Spain), $1.6 \mu \mathrm{L}$ of $\mathrm{MgCl}_{2}(50 \mathrm{mM}), 0.5 \mu \mathrm{L}$ of each primer $(20 \mathrm{mM})$, and $2 \mu \mathrm{L}$ of DNA template. A positive control with $H$ pylori DNA strain NCTC 11637 and a control of external contamination, consisting of qPCR mix without DNA were included in each qPCR analysis, and as negative control used E coli DNA strain ATCC 25992.

The qPCR was run under the following conditions: initial DNA denaturation step at $95^{\circ} \mathrm{C}$ for 10 minutes followed by 40 cycles of: $95^{\circ} \mathrm{C}$ for 10 seconds, $62^{\circ} \mathrm{C}$ for 5 seconds, and $72^{\circ} \mathrm{C}$ for $16 \mathrm{sec}-$ onds; and finally, one cycle at $72^{\circ} \mathrm{C}$ for 15 seconds and one at $40^{\circ} \mathrm{C}$ for 30 seconds. ${ }^{16}$ All raw and drinking water samples and controls were run in duplicate. A standard curve was constructed with 10 to $10^{6}$ genome copies of H pylori NCTC 11637 DNA16. Given that each $\mathrm{H}$ pylori genome has one copy of vacA gene, we assumed that one genome copy of $\mathrm{H}$ pylori was equivalent to one genomic unit $(\mathrm{GU})^{39}$.

The qPCR products were analyzed in $2 \%(\mathrm{w} / \mathrm{v})$ agarose gel electrophoresis prepared with $1 \times$ TAE Buffer (40 mM Tris-acetate, $1 \mathrm{mM}$ EDTA, pH $8.0 \pm 0.2$ ), and stained with $0.02 \%$ SYBR $^{\circledR}$ Safe-DNA Gel Stain (Invitrogen, USA), at run $80 \mathrm{~V}$ for 1 hour. The gel was visualized through the Gel Doc ${ }^{\mathrm{TM}} \mathrm{XR}^{+}$Imaging System Molecular Imager (BIO-RAD, USA). 100 bp Plus DNA ladder (Invitrogen ${ }^{\text {TM }}$ by Life Technologies $^{T M}$, USA) was used as a molecular weight marker.

The homology between the amplified sequences and the corresponding $\mathrm{H}$ pylori vacA gene fragment was performed by sequencing, using the Sanger method (Macrogen, Korea). Sequences were compared to the sequences published in GenBank according to Altschul et $\mathrm{al}^{40}$ by using BLAST software alignment tool (https://blast.ncbi. nlm.nih.gov/Blast.cgi).

\subsection{Detection and enumeration of fecal indicator bacteria}

The FIB monitored in both raw and drinking water samples were E coli, total coliforms, and spores of sulfite-reducing Clostridia. For the enumeration of $E$ coli and total coliforms, membrane filtration ISO 9308-1:2014 method $^{41}$ was used. Briefly, the raw water samples were serial 10 -fold diluted $\left(10^{-1}-10^{-4}\right)$, and subsequently, all the dilutions were filtered. One hundred $\mathrm{mL}$ of each drinking 
water sample was directly filtered. Then, the filters were put on Chromocult $^{\circledR}$ Coliform agar (Merck, Germany), and incubated at $36 \pm 2{ }^{\circ} \mathrm{C}$ for $21 \pm 3$ hours. The enumeration of the spores of sulfitereducing Clostridia was performed also by membrane filtration ISO 6461-2:1986 method. ${ }^{42}$ Both, raw and drinking water samples were heated a $75^{\circ} \mathrm{C}$ for 15 minutes. Afterward, the raw water samples were serial 10 -fold diluted $\left(10^{-1}-10^{-4}\right)$ and all the dilutions were filtered. Aliquots of $100 \mathrm{~mL}$ of the drinking water samples were directly filtered. The filters were placed on SPS (Sulfite polymyxin sulfadiazine) agar (Merck, Germany) and incubated under microaerophilic conditions in anaerobic jars (Oxoid, UK) with a gas-generating envelope (AnaeroGen ${ }^{\mathrm{TM}} 2.5 \mathrm{~L}$, Thermo Scientific, USA) at $37 \pm 2{ }^{\circ} \mathrm{C}$ for $44 \pm 4$ hours.

\section{5 | Physicochemical parameters analysis}

Water quality was evaluated from the physicochemical parameters obtained from the diary routine control of both raw and drinking water samples, by using the Standard Methods protocols. ${ }^{35} \mathrm{pH}$ and conductivity were measured by electrometric method (SM 4500-H-B and SM 2510-B, respectively). Turbidity was measured by nephelometric method (SM 2130-B), and in the drinking water, the free residual chlorine was measured by the Ferrous Titrimetric method-DPD (SM 4500-CL-F).

\subsection{Statistical analysis of the data}

All statistical analyses were conducted in IBM SPSS Statistics software package version 24.0. ${ }^{43}$ The data were analyzed with Bivariate statistical test. ${ }^{44}$ Qualitative data were described by using number and percent. Differences in data values were considered significant at $P<0.05$. Descriptive statistics were used to examine the distribution of $\mathrm{H}$ pylori contamination, fecal indicator bacteria, and physicochemical parameters.

In order to determine whether there is a correlation between the concentration of FIB (total coliforms, E coli, and spores of sulfite-reducing Clostridium) or physicochemical parameters $(\mathrm{pH}$, conductivity, turbidity, and free residual chlorine) and the presence of $\mathrm{H}$ pylori, the Spearman correlation coefficient $(\rho)$ and the Tau-b Kendall correlation coefficient were used. For all the analysis, $H$ pylori was used as independent variable and the fecal indicator bacteria and physicochemical parameters were used as dependent variables.

\section{3 | RESULTS}

\subsection{Helicobacter pylori in raw and drinking water}

During the sampling period (July 2015 to August 2016), H pylori DNA was detected by qPCR in the raw and drinking water samples, with $31 \%(30 / 155)$ and $38.7 \%(48 / 155)$ of positive samples, respectively (Figure 1A, B). From July to December (2015) H pylori was detected in all samples from both, raw and drinking water. Among the raw water samples collected in 2016, H pylori DNA was detected in all samples, except in February ones. In drinking water samples from July and August of 2016, H pylori DNA was not detected. In the rest of samples, it was detected in at least in one water sample.

In the raw water, $\mathrm{H}$ pylori DNA was quantified in 13 (8.4\%) of the positive samples, with concentrations ranging between $1.28 \times 10^{1}$ and $4.69 \times 10^{2}$ genomic units (GU) per $\mathrm{mL}$ (Figure $2 \mathrm{~A}, \mathrm{~B}$ ). In the drinking water samples, $\mathrm{H}$ pylori DNA could only be quantified in 20 (12.9\%) of the positive samples, with concentration values ranging from 5.77 to $2.12 \times 10^{3} \mathrm{GU}$ per sample (Table 1 and Table 2). In all the remaining positive samples, $C_{t}$ values were above the reliability threshold ( $>35$ cycles). Sequencing of all amplicons showed that the sequence of all of them was $98 \%-100 \%$ similar to a fragment of $\mathrm{H} \mathrm{py-}$ lori vacA gene sequence (GenBank accession numbers AF049653.1CP003904.1 AJ438914.1-U95971.1).

\subsection{Fecal indicator bacteria in raw and drinking water}

Throughout the sampling period, FIB were detected in all the raw water samples. Total coliforms were present in a range between $2.4 \times 10^{1}$ and $5.7 \times 10^{4} \mathrm{CFU} / 100 \mathrm{~mL}$; E coli between 2.0 and

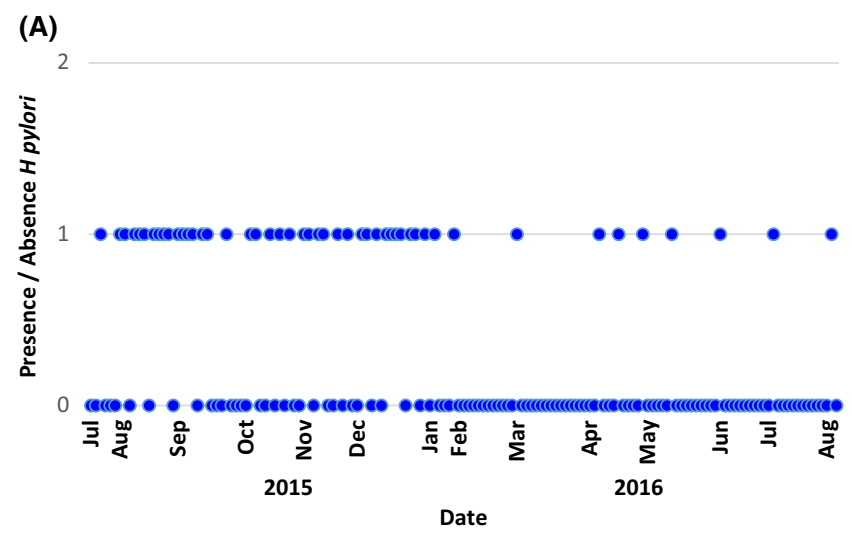

0: Absence of $H$. pylori, 1: Presence of $H$. pylori.

(B)

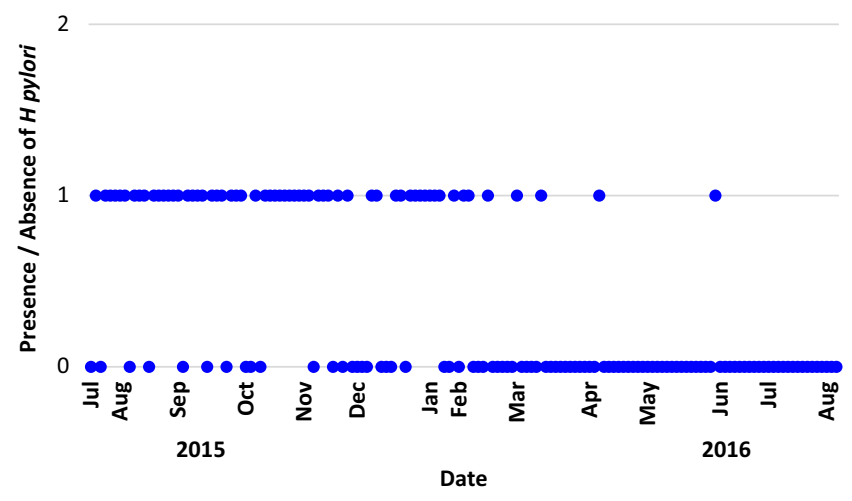

0: Absence of $H$. pylori, 1: Presence of $H$. pylori.

FIGURE 1 Presence/absence of Helicobacter pylori DNA detected by qPCR in water samples. (A) Presence/absence of $H$ pylori DNA in raw water from July 2015 to August 2016. (B) Presence/absence of $H$ pylori DNA in drinking water from July 2015 to August 2016. O, Absence of $\mathrm{H}$ pylori; 1, Presence of $\mathrm{H}$ pylori 
$3.0 \times 10^{3} \mathrm{CFU} / 100 \mathrm{~mL}$ and spores of sulfite-reducing Clostridia from 1.0 to $5.5 \times 10^{3} \mathrm{CFU} / 100 \mathrm{~mL}$. A high concentration of total coliforms was found in comparison with $E$ coli and spores of sulfite-reducing Clostridia (Table 1). In the drinking water samples, no FIB were detected throughout the sampling period (Table 2).$$
\text { (A) }
$$

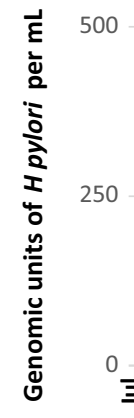

(B)

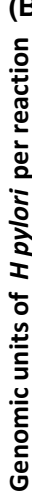

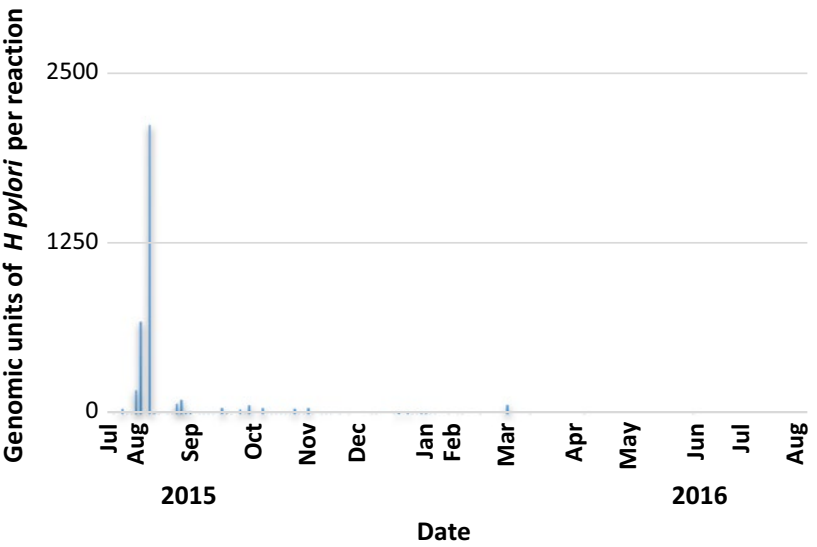

FIGURE 2 Genomic units of Helicobacter pylori DNA detected by qPCR in water samples. (A) Genomic units of $H$ pylori DNA per $\mathrm{mL}$ in raw water from July 2015 to August 2016. (B) Genomic units of $H$ pylori DNA per reaction in drinking water from July 2015 to August 2016

\section{3 | Physicochemical parameters in raw and drinking water}

The raw water quality parameters were those permitted by Colombian regulations for raw water samples to be used as a source of water for drinking water. The drinking water analyzed parameters were those required by Colombian regulations regarding water suitable for human consumption (Table 1; Table 2, respectively). According to the World Health Organization (WHO), the residual free chlorine in drinking water should be between 0.2 and $1.0 \mathrm{mg} / \mathrm{L} .{ }^{45}$ However, Colombian regulations allow chlorine concentrations between 0.3 and $2.0 \mathrm{mg} / \mathrm{L}^{46}(3)$.

\subsection{Associations among fecal indicator bacterial, physicochemical parameters, and $\mathrm{H}$ pylori in raw and drinking water}

Statistical analysis of the results for raw water did not show a significant association among fecal indicator bacteria concentration, $\mathrm{pH}$, and the presence/absence of $\mathrm{H}$ pylori DNA. We found a negative association, but not statistically significant, among turbidity, conductivity, and the presence of $\mathrm{H}$ pylori (Table 3). In the case of the drinking water, we did not find statistically significant association among fecal indicator bacteria concentration, conductivity, turbidity, $\mathrm{pH}$, and residual free chlorine with the presence/absence of H pylori DNA (Table 4).

\section{DISCUSSION}

Currently, US Environmental Protection Agency (EPA) includes $\mathrm{H}$ pylori in its Contaminant Candidate List (CCL), which comprises chemical and microorganisms contaminants that are known to be present in drinking water systems and are suspected to pose public health risk. ${ }^{3,47}$ However, data available on the presence of $\mathrm{H}$ pylori and the type of the water treatment in drinking water are limited. Thus, a quantitative microbial risk assessment (QMRA) has not yet been
TABLE 1 Characteristics of raw water samples from July 2015 to August 2016

\begin{tabular}{|c|c|c|c|c|}
\hline & $\mathrm{N}$ & Range & Median & Mean \\
\hline $\begin{array}{l}\text { H pylori genome } \\
\text { units } / \mathrm{mL}\end{array}$ & 155 & $1.28 \times 10^{1}-4.69 \times 10^{2}$ & $7.5 \times 10^{1}$ & $7.99 \times 10^{1}$ \\
\hline Turbidity (NUT) & 155 & $1.5-47.1$ & 7.1 & 7.6 \\
\hline Conductivity $(\mu \mathrm{S} / \mathrm{cm})$ & 155 & 8.1-110 & 41 & 41.6 \\
\hline $\mathrm{pH}$ & 155 & 6.1-7.26 & 6.8 & 6.69 \\
\hline $\begin{array}{l}\text { Total coliforms } \\
\text { (CFU/100 mL) }\end{array}$ & 155 & $2.4 \times 10^{1}-5.7 \times 10^{4}$ & $4.48 \times 10^{2}$ & $7.55 \times 10^{2}$ \\
\hline E coli (CFU/100 mL) & 155 & $2.0-3.0 \times 10^{3}$ & $5.6 \times 10^{1}$ & $6.20 \times 10^{1}$ \\
\hline $\begin{array}{l}\text { Spores of sulfite- } \\
\text { reducing Clostridia } \\
\text { (CFU/100 mL) }\end{array}$ & 155 & $1.0-5.5 \times 10^{3}$ & $5.1 \times 10^{1}$ & $3.91 \times 10^{1}$ \\
\hline
\end{tabular}

$\mu \mathrm{S} / \mathrm{cm}$, micro Siemens/centimeter; CFU/mL, colony forming unit/milliliter; N, samples number; NUT, nephelometric unit turbidity. 


\begin{tabular}{|lllll|}
\hline & N & Range & Median & Mean \\
\hline $\begin{array}{l}\text { H pylori genome units/ } \\
\text { reaction }\end{array}$ & 155 & $5.77-2.12 \times 10^{3}$ & $3.73 \times 10^{1}$ & $4.05 \times 10^{1}$ \\
\hline $\begin{array}{l}\text { Turbidity (NUT) } \\
\text { Conductivity }(\mu \mathrm{S} / \mathrm{cm})\end{array}$ & 155 & $0.1-1.3$ & 0.24 & 0.26 \\
\hline $\mathrm{pH}$ & 155 & $34-150$ & 68.3 & 73.1 \\
\hline $\begin{array}{l}\text { Free chlorine residual (FAC) } \\
\text { (mg/L) }\end{array}$ & 155 & $6.39-7.95$ & 6.77 & 6.83 \\
\hline $\begin{array}{c}\text { Total coliforms } \\
\text { (CFU/100 mL) }\end{array}$ & 155 & $0.79-2.0$ & 1.66 & 1.59 \\
\hline $\begin{array}{l}\text { E coli (CFU/100 mL) } \\
\text { Spores of sulfite-reducing }\end{array}$ & 155 & $<1^{*}$ & & $<1^{*}$ \\
\hline Clostridia (CFU/100 mL) & 155 & $<1^{*}$ & $<1^{*}$ & $<1^{*}$ \\
\hline
\end{tabular}

TABLE 2 Characteristics of drinking water samples from July 2015 to August 2016

$\mu \mathrm{S} / \mathrm{cm}$, micro Siemens/centimeter; CFU/mL, colony forming unit/milliliter; mg/L, milligram/liter; N, samples number; NUT, nephelometric unit turbidity.

${ }^{*}$ Detection limit of method analysis.

carried out for $\mathrm{H}$ pylori in the water ${ }^{48}$ and $\mathrm{H}$ pylori remains as a candidate while a standardized method for its detection and identification in environmental samples is implemented.

Multiple studies have confirmed the occurrence of $\mathrm{H}$ pylori in environmental and drinking waters around the world. ${ }^{5,16,17,49}$ Lu et $\mathrm{al}^{21}$ cultured $\mathrm{H}$ pylori from a sample from a canal along the US/Mexico border that was heavily contaminated with untreated raw sewage. Vesga et $\mathrm{al}^{17}$ also successfully cultured $\mathrm{H}$ pylori from influent and effluent water samples from drinking water treatment plants from Bogotá (Colombia). Together, these studies suggest that conventional chlorine disinfection treatments for water potability do not assurance the elimination of all pathogens, as is the case with $\mathrm{H}$ pylori.

A few studies have shown poor correlation between the presence of these organisms with that of fecal indicators bacteria such as total coliforms or $E$ coli. ${ }^{50-53}$ Thus, the presence of $\mathrm{H}$ pylori in water may not be accurately assessed by the use of traditional fecal indicator bacterial detection methods.

In this study, we used the Moore swab method, and a pre-enrichment step, to increase the effectiveness of detection of $\mathrm{H}$ pylori

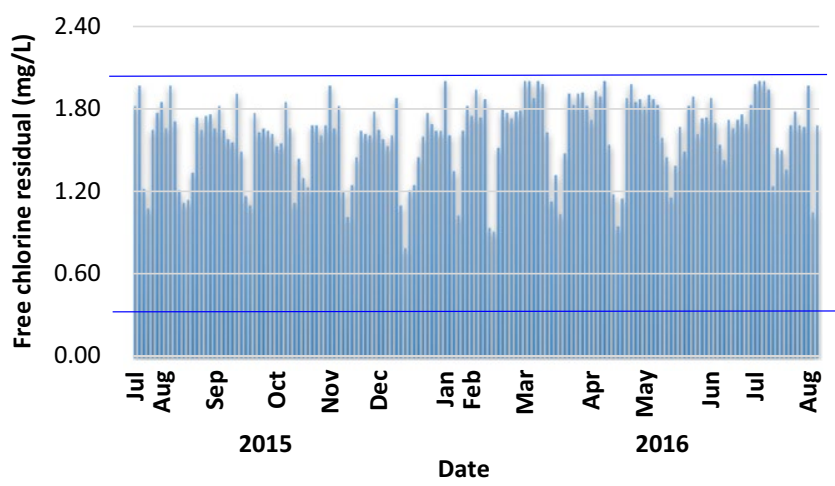

FIGURE 3 Residual free chlorine in drinking water from July 2015 to August 2016. The upper line in the free chlorine residual graph represents the upper limit of the Colombian regulations recommendation for FAC ( $2.0 \mathrm{mg} / \mathrm{L})$, and the lower line represents the minimum recommended FAC residual $(0.3 \mathrm{mg} / \mathrm{L})$ in drinking water. This method has proven to be useful for isolating different pathogen and enteric bacteria from low contaminated waters, surface water, drinking water, and soil. ${ }^{17,54,55}$

During the sampling period (July 2015 to August 2016), 31\% $(30 / 155)$ of the raw water samples and $38.7 \%(48 / 155)$ of the drinking water samples were positive for the presence of $H$ pylori DNA by qPCR. Although we were able to quantify $\mathrm{H}$ pylori DNA in $12.9 \%$ (20/155) of the drinking water samples, with mean levels between 5.77 and $2.12 \times 10^{3} \mathrm{GU} /$ reaction, these results do not represent the real level of contamination of the waters, as the sampling method included a pre-enrichment step. In the raw water samples, the concentration of $H$ pylori DNA could only be quantified in $8.4 \%(13 / 155)$ of the samples, with concentrations between $1.28 \times 10^{1}$ and $4.69 \times 10^{2}$ $\mathrm{GU} / \mathrm{mL}$.

Although the presence of DNA in a sample is not indicative of the presence of viable cells, we considered that detection of $\mathrm{H} \mathrm{py}$ lori DNA by qPCR followed by specific sequencing of the amplicons ensured us to detect the presence of $H$ pylori in the samples, which was the aim of this work. It is widely known that the cultivation of this bacterium from environment is very difficult. Moreover, under adverse environmental circumstances $\mathrm{H}$ pylori cells enter in a Viable But Not Culturable stage in which culture is not possible. ${ }^{16}$ Molecular methods for estimating the presence of exclusively viable cells in water, such as detection of mRNA, PMA-PCR, or DVV-FISH have been previously used in very few occasions and need further investigations. ${ }^{56}$

In the last decades, many studies have focused on the relationship between water contamination indicators and pathogens. Clostridium $s p$ has been proposed as an indicator of the presence of Giardia cysts and Cryptosporidium oocysts in environmental samples, due to the formation of spores that would have a similar resistance structures as these parasites. ${ }^{57-59}$ It has been previously suggested that $\mathrm{H}$ pylori survives in the environment in a viable but nonculturable form. ${ }^{60,61}$ Considering that this forms could be more resistant than culturable cells in environmental samples and that their behavior may vary in 
TAB LE 3 Statistical data showing the relationship of fecal indicator bacteria, turbidity, $\mathrm{pH}$, and conductivity, with the presence/absence of Helicobacter pylori in raw water

\begin{tabular}{|c|c|c|c|c|c|c|}
\hline Parameter & \multicolumn{3}{|c|}{ Tau-b Kendall correlation coefficient } & \multicolumn{3}{|c|}{ Spearman correlation coefficient } \\
\hline \multicolumn{7}{|l|}{ H pylori } \\
\hline Turbidity & -0.115 & 0.083 & 155 & -0.140 & 0.083 & 155 \\
\hline Conductivity & -0.085 & 0.203 & 155 & -0.103 & 0.204 & 155 \\
\hline Total coliform & -0.088 & 0.182 & 155 & -0.107 & 0.183 & 155 \\
\hline E coli & -0.096 & 0.154 & 155 & -0.115 & 0.154 & 155 \\
\hline $\begin{array}{l}\text { Spores of sulfite-reduc- } \\
\text { ing Clostridia }\end{array}$ & -0.047 & -0.047 & 155 & -0.057 & 0.479 & 155 \\
\hline
\end{tabular}

$\mathrm{N}$, samples number.

relation to traditional indicators of fecal contamination (total coliforms and $E$ coli), in this study the presence of the spores of sulfite-reducing Clostridia was evaluated as a possible indicator of the presence and or absence of $\mathrm{H}$ pylori in raw and drinking water. In raw water samples, the concentration of the spores of sulfite-reducing Clostridia was found to range between 1.0 and $5.5 \times 10^{3} \mathrm{CFU} / 100 \mathrm{~mL}$, and in drinking water samples they were not detected. Statistical analysis showed that there is no direct relationship between the detection of spores of sulfite-reducing Clostridia and the presence/absence of $\mathrm{H}$ pylori in both, raw or drinking water. This suggests that the presence of $\mathrm{H}$ pylori in water samples cannot be evaluated by detecting the spores of sulfite-reducing Clostridia and those variations that may occur in the concentration cannot be taken as indicative to suppose the presence or absence of $H$ pylori in raw or drinking water.

Colombian regulations (Decree 1594, 1984) ${ }^{62}$ stipulate minimum physical, chemical, and microbiological requirements of water to consider it as drinking water. In our study, we found that the values of the average concentration of total coliforms in the raw water samples evaluated are within the maximum values allowed (maximum value $2 \times 10^{4} \mathrm{CFU} / 100 \mathrm{~mL}$ ).

Quantification of fecal indicator bacteria in all the drinking water samples complied the values established in the resolution $2115,{ }^{46}$ which states that the maximum value accepted for total coliforms and $E$ coli must be 0 or $<1 \mathrm{CFU} / 100 \mathrm{~mL}$, using the membrane filtration technique. Statistical analysis showed that there was no direct relationship between assessed indicators of fecal contamination and the presence of $\mathrm{H}$ pylori in the raw and drinking water samples. This suggests that the presence of $H$ pylori in water cannot be evaluated by detecting the fecal indicator bacteria and variations that may occur in the concentration of total coliforms or $E$ coli cannot be taken as indicative for assuming the presence or absence of $\mathrm{H}$ pylori in the raw or drinking water.

There are limited data on the association of the fecal indicators bacteria and the presence of $H$ pylori in water. Braganca et $a^{63}$ and Baker \& Hegarty, ${ }^{50}$ in their work with biofilms, showed that $\mathrm{H}$ pylori was more resistant to chlorination than $E$ coli. Hegarty et al ${ }^{64}$ were

TAB LE 4 Statistical data showing the relationship of fecal indicator bacteria, turbidity, $\mathrm{pH}$, conductivity, and free available chlorine residual, with the presence/absence of Helicobacter pylori in drinking water

\begin{tabular}{|c|c|c|c|c|c|c|}
\hline Parameter & \multicolumn{3}{|c|}{ Tau-b Kendall correlation coefficient } & \multicolumn{3}{|c|}{ Spearman correlation coefficient } \\
\hline \multicolumn{7}{|l|}{ H pylori } \\
\hline Turbidity & -0.005 & 0.937 & 155 & -0.006 & 0.937 & 155 \\
\hline Conductivity & 0.015 & 0.820 & 155 & 0.018 & 0.821 & 155 \\
\hline $\begin{array}{l}\text { Free Chlorine residual } \\
\text { (FAC) }\end{array}$ & -0.082 & 0.215 & 155 & -0.100 & 0.216 & 155 \\
\hline Total coliform & 0.0 & 0.0 & 155 & 0.0 & 0.0 & 155 \\
\hline E coli & 0.0 & 0.0 & 155 & 0.0 & 0.0 & 155 \\
\hline $\begin{array}{l}\text { Spores of sulfite-reduc- } \\
\text { ing Clostridia }\end{array}$ & 0.0 & 0.0 & 155 & 0.0 & 0.0 & 155 \\
\hline
\end{tabular}

$\mathrm{N}$, samples number. 
the first to evaluate the relationship of the presence of $H$ pylori and $E$ coli in waters. They did not find any correlation between the presence of $H$ pylori DNA in drinking water and the presence of $E$ coli, and suggested that this indicator may fail when it is used as the only test of water potability.

In this study, we did not either found statistically significant relationships between the physicochemical parameters (turbidity, conductivity, $\mathrm{pH}$, and residual free chlorine) and the presence/absence of $\mathrm{H}$ pylori in the raw and drinking water samples. This suggests that the presence/absence of $\mathrm{H}$ pylori in water does not depend on the turbidity, conductivity, $\mathrm{pH}$, and residual free chlorine and variations that may occur in the values of this physicochemical parameters cannot be used as indicative for assuming the presence or absence of $H$ pylori in the raw or drinking water.

In this study, different detection and quantification methods were used for the microorganisms evaluated (culture for detection and quantification of FIB and GPCR for H pylori DNA). Therefore, it is proposed to carry out new studies, using molecular methods for the detection of FIB. Furthermore, the "Moore swab" method was used for the concentration of $H$ pylori and standardized qPCR for the detection and quantification of DNA from drinking water samples. These methods can be used in future research to determine the levels in which $\mathrm{H}$ pylori is found and the possible effects that its presence in drinking water may have on public health.

\section{5 | CONCLUSIONS}

To our knowledge, this is the first long-time sampling study of raw water and drinking water contamination with $\mathrm{H}$ pylori in Bogotá, Colombia. During 1-year sampling period, we detected $H$ pylori DNA in $31 \%$ of the raw water samples and $38.7 \%$ of the drinking water samples, using qPCR, which suggests that there is continued contamination of the raw water with $\mathrm{H}$ pylori.

While $H$ pylori was often found in samples containing FIB, the presence and abundance of FIB was not predictive of $H$ pylori DNA present or absence. Furthermore, we found no significant relationship between physicochemical parameters and $\mathrm{H}$ pylori presence in both raw and drinking water.

Our results highlight the importance of performing periodic controls for the detection of specific pathogens in water, since the only control of fecal contamination by traditional indicators such as total coliforms, E coli, or spores of sulfite-reducing Clostridia, cannot be indicative of the presence of pathogens of great relevance for public health, as $\mathrm{H}$ pylori.

\section{ACKNOWLEDGEMENTS}

This work was supported by COLCIENCIAS, Project 120356933870 , CTO 642-2013, Colombia, and AICO/2018/273 Project Grant from Generalitat Valenciana, Spain. We greatly acknowledge the collaboration of the Aqueduct and Sewage Company of Bogotá (EAB), Colombia.

\section{CONFLICT OF INTEREST}

The authors have no conflict of interest.

\section{ORCID}

Fidson-Juarismy Vesga (iD https://orcid.org/0000-0001-9753-3230

\section{REFERENCES}

1. NRCC-National Research Council Canada. Monitoring Water Quality in the Distribution System. National Guide to Sustainable Municipal Infrastructure, Version 1.0. Federation of Canadian Municipalities and Canada. Ottawa, Canada: NRCC; 2004.

2. Mansour-Rezaei S, Naser G, Malekpour A, Karney B. Contaminant intrusion in water distribution systems. J Am Water Works Assoc. 2013;E278-290.

3. Environmental Protection Agency - USEPA. Contaminant Candidate List $(\mathrm{CCL})$ and regulatory determination. Draft Contaminant Candidate List 4-CCL 4. 2016. https://www.epa.gov/ccl/draft-contaminant-candidate-list-4-ccl-4. (Accessed January 2019).

4. Khean-Lee G, Wah-Kheong C, Shiota S, Yamaoka Y. Epidemiology of Helicobacter pylori Infection and public health implications. Helicobacter. 2011;16(Suppl. 1):1-9.

5. Moreno Y, Ferrús MA. Specific detection of cultivable Helicobacter pylori cells from wastewater treatment plants. Helicobacter. 2012;17:327-332.

6. Aziz RK, Khalifa MM, Sharaf RR. Contaminated water as a source of Helicobacter pylori infection. J Adv Res. 2015;6(4):539-547.

7. Hooi J, Lai WY, Ng WK, et al. Global prevalence of Helicobacter pylori infection: systematic review and meta-analysis. Gastroenterology. 2017;153:420-429.

8. Campuzano-Maya G, Hoyos-Castaño D, Calvo-Betancur V, SuárezRamírez O, Lizcano-Cardona D, Rojas-Arbeláez C. Prevalencia de la infección por Helicobacter pylori en médicos de Medellín Colombia. Acta Gastroenterol Latinoam. 2007;37(2):99-103.

9. Voytek MA, Ashen JB, Kirshtein JD, Landa ER, Fogarty LR. Detection of Helicobacter pylori and fecal indicator bacteria in five North American rivers. J Water Health. 2005;3:405-422.

10. Boehnke KF, Eaton KA, Valdivieso M, Baker LH, Xi C. Animal model reveals potential waterborne transmission of Helicobacter pylori infection. Helicobacter. 2015;20:326-333.

11. Agency for Research on Cancer (IARC). Working group IARC monographs on the evaluation of carcinogenic risk to humans. Schistosomas, liver flukes and Helicobacter pylori, vol. 61. Lyon, France: International; 1994.

12. Percival SL, Suleman L. Biofilms and Helicobacter pylori: Dissemination and persistence within the environment and host. World J Gastroint Pathophy. 2014;5(3):122-132.

13. Azevedo NF, Almeida C, Cerqueira L, Dias S, Keevil CW, Vieira MJ. Coccoid form of Helicobacter pylori as a morphological manifestation of cell adaptation to the environment. Appl Environ Microbiol. 2007;73(10):3423-3427.

14. Li L, Mendis N, Trigui H, Oliver JD, Faucher SP. The importance of the viable but non-culturable state in human bacterial pathogens. Front Microbiol. 2014;5:258.

15. Hulten $\mathrm{K}, \mathrm{Han} \mathrm{Sw}$, Enroth $\mathrm{H}$, et al. El-Zaatari F. Helicobacter pylori in the drinking water in Peru. Gastroenterology. 1996;110:1031-1035.

16. Santiago P, Moreno $Y$, Ferrús MA. Identification of Viable Helicobacter pylori in drinking water supplies by cultural and molecular techniques. Helicobacter. 2015;20:252-259.

17. Vesga FJ, Moreno Y, Ferrús MA, Campos C, Trespalacios AA. Detection of Helicobacter pylori in drinking water treatment plants 
in Bogotá, Colombia, using cultural and molecular techniques. Intern J Hyg Environ Health. 2018;221:595-601.

18. Orta de Velásquez MT. Yáñez Noguez I, Casasola Rodríguez B, Román PI. Effects of ozone and chlorine disinfection on VBNC Helicobacter pylori by molecular techniques and FESEM images. Environ Techn. 2016;8:39.

19. Moreno Y, Ferrús MA, Alonso JL, Jiménez A, Hernández J. Use of fluorescent in situ hybridization to evidence the presence of Helicobacter pylori in water. Water Res. 2003;37:2251-2256.

20. Al-Sulami A, Al-Edani TAA, Al-Abdula AA. Culture method and PCR for the detection of Helicobacter pylori in drinking water in Basrah Governorate Iraq. Gastroenterol Res Pract. 2012;2012:245167.

21. Lu Y, Redlinger TE, Avitivia R, Galindo A, Goodman K. Isolation and genotyping of Helicobacter pylori from untreated municipal wastewater. Appl Environ Mibrobiol. 2002;68(3):1436-1439.

22. Adams BL, Bates TC, Oliver JD. Survival of Helicobacter pylori in a natural freshwater environment. Appl Environ Microbiol. 2003;69:7462-7466.

23. McDaniels AE, Wymer L, Rankin C, Haugland R. Evaluation of quantitative real time PCR for the measurement of Helicobacter pylori at low concentrations in drinking water. Wat Res. 2005;39:4808-4816.

24. Montero-Campos V, Hernandez-Soto A, Camacho-Sandoval J. Culture and molecular identification of Helicobacter pylori in drinking water from areas of high and low incidence of gastric cancer in Costa Rica. Open J Med Microbiol. 2014;4:261-269.

25. Bai X, Xi C, Wu J. Survival of Helicobacter pylori in the wastewater treatment process and the receiving river in Michigan, USA. J Wat Health. 2016;14(4):692-698.

26. Rodríguez DC, Pino N, Peñuela G. Microbiological quality indicators in waters of dairy farms: detection of pathogens by PCR in real time. Sci Tot Environ. 2012;428:314-318.

27. Wu J, Long S, Das D, Dorner S. Are microbial indicators and pathogens correlated? A statistical analysis of 40 years of research. $J$ Water Health. 2011;9:265-278.

28. Luby SP, Halder AK, Huda TM, et al. Microbiological contamination of drinking water associated with subsequent child diarrhea. Am J Trop Med Hyg. 2015;93(5):904-911.

29. Levy K, Hubbard AE, Nelson KL, Eisenberg JN. Drivers of water quality variability in northern coastal Ecuador. Environ Sci Technol. 2009;43:1788-1797.

30. Holvoet K, Sampers I, Seynnaeve M, Uyttendaele M. Relationships among hygiene indicators and enteric pathogens in irrigation water, soil and lettuce and the impact of climatic conditions on contamination in the lettuce primary production. Int J Food Microbiol. 2014;171:21-31.

31. Castro-Ibáñez I, Gil MI, Tudela JA, Ivanek R, Allende A. Assessment of microbial risk factors and impact of meteorological conditions during production of baby spinach in the Southeast of Spain. Food Microbiol. 2015;49:173-181.

32. Zhang Y, Riley LK, Lin M, Hu Z. Determination of low-density Escherichia coli and Helicobacter pylori suspensions in water. Wat Res. 2012;46:2140-2148.

33. Boehnke K, Brewster RK, Sánchez BN, et al. An assessment of drinking water contamination with Helicobacter pylori in Lima, Peru. Helicobacter. 2018;23:1-8.

34. Griffith JF, Weisberg SB, Arnold BF, Cao Y, Schiff KC, Colford JM. Colford JrJM. Epidemiologic evaluation of multiple alternate microbial water quality monitoring indicators at three California beaches. Wat Res. 2016;94:371-381.

35. APHA/AWWA/WEF. Standard Method for the Examination of Water and Wastewater (22nd ed.). Washington, DC: American Public Health Association/ American Water Works Association/ Water Environment Federation; 2012.

36. Organización Panamericana de la Salud - OPS/ WHO. Procedimientos para la búsqueda de Vibrio cholerae en muestras ambientales; 2010, http://www.paho.org/hq/dmdocuments/2010/ Muestreo_ambiental_V_cholerae.pdf?ua=1. (Accessed May 2015).

37. Enroth H, Engstrand L. Immunomagnetic separation and PCR for detection of Helicobacter pylori in water and stool specimens. J Clin Microbiol. 1995;33(8):2162-2165.

38. Nilsson H, Blom J, Al-Soud W, Ljungh A, Andersen L, Wadström T. Effect of cold starvation, acid stress, and nutrients on metabolic activity of Helicobacter pylori. Appl Environ Microbiol. 2002;68(1):11-19.

39. Foegeding NJ, Caston RR, McClain MS, Ohi MD, Cover TL. An overview of Helicobacter pylori VacA toxin biology. Toxins. 2016;8:173.

40. Altschul SF, Madden TL, Schäffer AA, et al. Gapped BLAST and PSIBLAST: a new generation of protein database search programs. Nucl Acid Res. 1997;25(17):3389-3402.

41. Organization for Standardization (ISO): 9308-1. Water QualityEnumeration of Escherichia coli and Coliform Bacteria - Part 1: Membrane Filtration Method for Water with low bacteria background flora. International; flora. 2014.

42. International Organization for Standardization (ISO): 6461-2. Water Quality- Detection and Enumeration of the Spores of SulfiteReducing Anaerobes (Clostridia) - Part 2: Method by Membrane Filtration. 1986.

43. González JA. Manual básico SPSS. Universidad de Talca. Talca, Chile. 2009, P. 70.

44. Mondragón MA. Use of the correlation spearman in a study of intervention in physiotherapy. Mov Cient. 2014;8(1):98-104.

45. World Health Organization. Guidelines for Drinking-Water Quality (3rd edition), incorporating the first and second addenda. Volume 1. Recommendations. Geneva: WHO, 2008, 668 pages. http://www. who.int/water_sanitation_health/dwq/fulltext.pdf. (Accessed May 2018).

46. de Salud Ministerio. Resolution 2115 of the 2007. Web site: http:// www.minsalud.gov.co/. (Accessed May 2018).

47. Environmental Protection Agency - USEPA. Contaminant Candidate List (CCL) and Regulatory Determination. Draft Contaminant Candidate List 1-CCL 1; 2004. https://www.epa. $\mathrm{gov} / \mathrm{ccl} / \mathrm{draft}$-contaminant-candidate-list-1-ccl-1\#microbial-list. (Accessed June 2018).

48. Ryan M, Hamilton K, Hamilton M, Haas CN. Evaluating the potential for a Helicobacter pylori drinking water guideline. Risk Analysis. 2014;34(9):1651-1992.

49. Bahrami AR, Rahimi E, Safaei HG. Detection of Helicobacter pylori in city water, dental units' water, and bottled mineral water in Isfahan Iran. Sci World J. 2013;2013:280510

50. Baker $\mathrm{KH}$, Hegarty JP. Presence of Helicobacter pylori in drinking water is associated with clinical infection. Scand J Infect Dis. 2001;33:744-746.

51. Mazari-Hiriart M, López-Vidal Y, Calva JJ. Helicobacter pylori in water systems for human use in Mexico city. Water Sci Technol. 2001;43(12):93-98.

52. Travis PB, Goodman KJ, O'Rourke KM, et al. The association of drinking water quality and sewage disposal with Helicobacter pylori incidence in infants: the potential role of water-borne transmission. J Wat Health. 2010;8(1):192-203.

53. Twing KI, Kirchman DL, Campbell BJ. Temporal study of Helicobacter pylori presence in coastal freshwater, estuary and marine waters. Wat Res. 2011;45:1897-1905.

54. Fernandez $\mathrm{H}$, Otth L, Wilson $\mathrm{M}$. Isolation of thermo tolerant species of Campylobacter from river water using two collection methods. Arch Med Vet. 2003;35:95-97.

55. McEgan R, Rodrigues C, Sbodio A, Suslow TV, Goodridge LD, Danyluk MD. Detection of Salmonella spp. from large volumes of water by modified Moore swabs and tangential flow filtration. Lett App Microbiol. 2012;56:88-94.

56. Araujo Boira R, Hanninen ML. Helicobacter pylori. In: Rose JB, Jiménez-Cisneros B, (eds). Global Water Pathogen Project. (A. 
Pruden, N. Ashbolt and J. Miller (eds) Part 3 Bacteria). Michigan State University. E. Lansing, MI: UNESCO:2017. http://www.waterpathogens.orghttp://www.waterpathogens.org/book/helicobacter-pylorihttps://doi.org/10.14321/waterpathogens.25.

57. Ferguson C, Coote B, Ashbolt L, Stevenson I. Relationships between indicators, pathogens and water quality in an estuarine system. Wat Res. 1996;30:2045-2054.

58. Harwood VJ, Levine AD, Scott TM, et al. Validity of the indicator organism paradigm for pathogen reduction in reclaimed water and public health protection. Appl Environ Microbiol. 2005;71(6):3163-3170.

59. Cheng HW, Broaders MA, Lucy FE, Mastitsky SE, Graczyk TK. Determining potential indicators of Cryptosporidium oocysts throughout the wastewater treatment process. Water Science Technol. 2012;65(5):875-882.

60. Nayak AK, Rose JB. Detection of Helicobacter pylori in sewage and water using a new quantitative PCR method with $\mathrm{SYBR}^{\circledR}$ green. J Appl Microbiol. 2007;103:1931-1941.

61. Saito N, Konishi K, Sato F, Kato M, Takeda H, Sugiyama T. Plural transformation-processes from spiral to coccoid Helicobacter pylori and its viability. J Infec. 2003;46:49-55.
62. Ministerio del Medio Ambiente. Decree 1594 of the 1984 . Web site. http:// www.minambiente.gov.co/. (Accessed May 2018).

63. Braganca SM, Azevedo NF, Simoes LC, Keevil CW, Vieira MJ. Use of fluorescent in situ hybridization for the visualization of Helicobacter pylori in real drinking water biofilms. Wat Sci Techn. 2007;55(8-9):387-393.

64. Hegarty JP, Dowd MT, Baker KH. Occurrence of Helicobacter pylori in surface water in the United States. J Appl Microbiol. 1999;87:697-701.

How to cite this article: Vesga F-J, Moreno Y, Ferrús MA, Ledesma-Gaitan LM, Campos C, Trespalacios AA. Correlation among fecal indicator bacteria and physicochemical parameters with the presence of Helicobacter pylori DNA in raw and drinking water from Bogotá, Colombia. Helicobacter. 2019;24:e12582. https://doi.org/10.1111/hel.12582 